\title{
Condom Use Before Marriage and Its Correlates: Evidence from India
}

\author{
By K.G.Santhya, \\ Rajib Acharya and \\ Shireen J. \\ Jejeebhoy \\ K. G. Santhya and \\ Rajib Acharya are \\ associates, and \\ Shireen J. Jejeebhoy is \\ senior associate-all at \\ the Population \\ Council, New Delhi.
}

\author{
CONTEXT: Little evidence is available from India concerning young people's use of condoms in premarital \\ relationships.
}

METHODS: Data from a subnationally representative study of Indian youth conducted in 2006-2008 were used to assess condom use in premarital relationships. Analyses used survey data from 2,408 married or unmarried youth aged 15-24 who had had premarital sex, and qualitative data from 271 such youth who completed in-depth interviews. Logistic regression was used to identify characteristics associated with four measures of condom use (ever-use, consistent use, use at first sex and use at last sex).

RESULTS: Only $7 \%$ of young women and $27 \%$ of young men who had had premarital sex had ever used condoms. Among both sexes, discomfort with approaching a provider or pharmacist for condoms was inversely correlated with most measures of condom use (odds ratios, 0.5 ), while having peers who had had premarital sex was generally positively correlated (1.6-2.9). Females who had had premarital sex only with nonromantic partners were less likely than those with only romantic partners to have used a condom at last sex (0.2), while males were generally more likely to use condoms with nonromantic than romantic partners (1.5-1.6). Among men, education level, age at sexual initiation and neighborhood economic status were positively associated with use.

CONCLUSION: Programs that encourage condom use are needed. Service delivery structures should be modified to enable youth to obtain condoms easily and privately.

International Perspectives on Sexual and Reproductive Health, 2011,37(4):170-180, doi: 10.1363/3717011

India has a long history of promoting condom use. It did so initially as part of its family welfare and STD control programs, and later, with the emergence of the HIV epidemic, as part of its HIV/AIDS control program. Nonetheless, condom use, in both premarital and marital relationships, remains limited in India. Findings from the 2005-2006 National Family Health Survey revealed that among unmarried women and men aged 15-24 who had had sex in the past year, just $18 \%$ and $37 \%$, respectively, had used a condom the last time they had had sex; ${ }^{1}$ among married young women, just $5 \%$ were currently using condoms. ${ }^{2}$ Several small- and large-scale studies that explored the premarital sexual behavior of Indian youth have also found that condom use is limited. ${ }^{3-8}$

Studies exploring correlates of condom use in India have generally focused on married men and women of reproductive age, or on such vulnerable groups as female sex workers, clients of sex workers, people living with HIV, migrants and men who have sex with men..$^{9-18}$ Few studies have examined factors associated with young people's use of condoms, particularly in premarital relationships. 6,19,20

Evidence from studies conducted in other countries suggests that condom use among youth in premarital sexual relationships is correlated with a number of individual, partner, relationship and family factors. At the individual level, such factors as education, self-efficacy, perceptions about the benefits of condom use, perceived infection risk, household economic status and urban residence are positively associated with condom use, ${ }^{21-25}$ while early sexual initiation and substance use are negatively associated. ${ }^{21,22,24-27}$ Partner and relationship characteristics are also important: Condom use is less likely in casual than in steady relationships, and among young women who had initiated sex with an older rather than same-age partner. ${ }^{22,25,28,29}$ At the family level, such factors as parental disapproval of premarital sex, as well as higher levels of parental involvement, connectedness and communication, are associated with condom use among youth. ${ }^{30,31}$

The few available Indian studies on this topic have found that among young men, condom use within premarital relationships is positively associated with urban residence, older age at first sex and type of sexual partner (condom use is less likely with acquaintances or neighbors, and more likely with sex workers, than with girlfriends). ${ }^{6,19}$ Only one study explored the correlates of condom use among sexually experienced young women; none of the covariates included in the analysis were associated with condom use. ${ }^{6}$

This article examines the extent to which Indian youth who were sexually experienced before marriage used condoms in their premarital relationships, and the factors associated with such use. 


\section{Study Setting}

Our data were drawn from a study conducted among representative samples of youth from six Indian states: Andhra Pradesh, Bihar, Jharkhand, Maharashtra, Rajasthan and Tamil Nadu. Together, youth in these states account for 39\% of the total youth population (aged 15-24) in the country, ${ }^{32}$ and their distributions by age, level of literacy, religion, caste and marital status are similar to those of the youth population nationally. ${ }^{33}$

The six states were purposively selected to reflect the regional diversity within India in terms of the social, economic and demographic characteristics of the population, and thus lie at the extremes of the country's socioeconomic and cultural spectrums. Andhra Pradesh, Maharashtra and Tamil Nadu are among the more economically progressive states in the country, while Bihar, Jharkhand and Rajasthan are among the less developed states. ${ }^{34} \mathrm{Ma}-$ harashtra and Tamil Nadu are among the most urbanized states, while Bihar, Jharkhand and Rajasthan are among the least urbanized. ${ }^{35}$ The prevalence of HIV among women attending antenatal clinics ranges from $0 \%$ in Jharkhand to 1\% in Andhra Pradesh. ${ }^{36}$ Condom use remains limited in all six states; just 1-6\% of married, reproductive-age women report current use of condoms. ${ }^{1}$ Likewise, just 2-9\% of sexually experienced men aged 15-49 reported that they had used a condom the last time they had had sex. ${ }^{37-42}$

\section{METHODS}

\section{Data}

The study comprised three phases: an initial qualitative phase, a survey and subsequent in-depth interviews with survey respondents who had reported certain experiences (such as premarital sex). Data presented in this article are drawn from the survey and the in-depth interviews.

The survey focused on married and unmarried women aged 15-24, unmarried men aged 15-24 and (because relatively few men had married at a young age) married men aged 15-29. Rural and urban areas were treated as independent sampling domains; a multistage sampling design was adopted for each domain. In each primary sampling unit, households were selected by systematic sampling; within each selected household, no more than one married and one unmarried respondent were interviewed.

Fieldwork was undertaken in Jharkhand, Maharashtra and Tamil Nadu in 2006-2007, and in Andhra Pradesh, Bihar and Rajasthan in 2007-2008. Using a structured questionnaire, the field investigators interviewed 50,848 youth. Response rates for the survey were 84-90\%; fewer than $1 \%$ of selected respondents refused to participate. The study tools were translated into local languages (Hindi, Marathi, Tamil and Telugu) and the interviews were conducted in these languages; transcripts of the indepth interviews were translated into English by professional translators.

Because young people may have been reluctant to disclose having had premarital sex, we took several measures to reduce potential underreporting. First, in presurvey focus group discussions, we probed the vocabulary used by youth to describe their romantic relationships and the situations in which they had had sex; we incorporated these terms and scenarios into the final survey instrument's questions related to romantic and sexual relationships. Second, the instrument introduced potentially sensitive or embarrassing questions in a gradual way. Third, in order to help respondents accurately recall sexual experiences with different types of partners, interviewers first asked respondents whether they had ever engaged in sexual intercourse with a romantic partner; they subsequently asked about other types of partners, such as casual partners and (for young men) sex workers. Fourth, recognizing the reluctance of youth to disclose sexual experiences in face-to-face interviews, at the conclusion of the interview we asked respondents to report their premarital sexual experience on a card, which they placed in an envelope that they then sealed. * Finally, efforts were made to ensure that youth were comfortable revealing sensitive behaviors. For example, interviewers were young and were trained to build rapport, discuss sensitive experiences in empathetic and matter-of-fact ways and generally make respondents feel comfortable about the topics to be discussed during the interview; interviews were held at times and places that provided maximum privacy for the respondent; and in cases in which family members attempted to participate in or overhear the interview, another interviewer was called upon to conduct an informal discussion with the family members so as to ensure privacy for the respondent's interview.

Overall, $3 \%$ of young women and $12 \%$ of young men reported during the survey interviews that they had had premarital sex; ${ }^{33}$ data presented in this article are restricted to these youth (821 young women and 1,587 young men; married men aged 25-29 were excluded to enable comparisons). In addition, in-depth interviews were conducted with 344 respondents; data from the 271 who reported having had premarital sex were included in the current analysis. Although the instruments used in the study contained questions assessing sexual experiences with samesex partners, these questions were not as detailed as those used to assess experiences with opposite-sex partners, and same-sex sexual relationships were considerably underreported.

\section{Variables}

- Outcomes. We created four key outcome indicators: everuse of condoms, consistent use of condoms, condom use at first sex and (among currently unmarried youth only) condom use at last sex. Respondents were asked about consistent condom use only with regard to their first and

\footnotetext{
*At the conclusion of the interview, youth were asked to mark a blank card indicating whether they had ever had premarital sex, place the card in an envelope, seal it and return it to the interviewer. Respondents were informed that only the principal investigators would be able to link the information provided in the envelope with that provided in the main body of the questionnaire.
} 
most recent romantic partners, partners with whom they had exchanged sex for money or gifts and, for young men only, sex workers and married women. Youth who reported sex with any of these partners were asked whether they had used condoms always, sometimes or not at all with each partner, and those who reported having always used condoms with all of these partners were categorized as having used condoms consistently. Information on condom use was not obtained for youth who reported sexual experiences with romantic partners other than the first or most recent, with casual sex partners or with their spouse before marriage (in a parent-arranged marriage), or for forced sex with a nonromantic partner; hence, our consistent condom use indicator may not be comprehensive. However, only $1 \%$ of young women and $3 \%$ of young men who had had premarital sex reported having had sex with such partners.

- Other measures. Our selection of other variables was informed by the available literature. At the individual level, we included age at the time of premarital sexual initiation, years of schooling completed at sexual initiation, whether the respondent had worked before age 15 , place of residence (urban or rural), religion (Hindu, Muslim or other) and caste. Information on years of schooling was obtained from the life event calendar that respondents completed; this approach is considered one of the most effective ways of minimizing recall error. The life event calendar recorded educational experiences starting at age 12; if by that age a respondent both had had sex and had discontinued schooling, the highest level of schooling successfully completed (recorded in response to a separate question) was used as the measure of schooling completed at sexual initiation. All respondents who had had premarital sex before age 12 had discontinued schooling by age 12 .

We also included measures of exposure to family life or sex education (whether the respondent had ever received such education in school or through programs sponsored by the government or nongovernmental organizations) and exposure to mass media. The latter measure was based on responses to a question asking how frequently the respondent was exposed to television or films (never, sometimes or often); if he or she answered in numerical terms, rather than choosing a categorical option, a response of three or more exposures per week was classified as "often" and less frequent exposure as "sometimes." We considered those who were exposed often to be frequently exposed. An indicator of perceived self-efficacy, reflecting youth's perceived ability to confront a person who had said or done something wrong to them, was also included. To account for respondents' access to sexual and reproductive health services, such as the ability to obtain condoms, we included a proxy indicator that measured whether youth perceived that they could approach a health care provider or a pharmacist for contraceptives.

A variable that indicated the types of partners with whom the respondent had had sex before marriage was also included. Youth were categorized as having had ro- mantic partners, other partners or both romantic and other partners on the basis of their answers to several questions. First, respondents were asked whether they had ever had a boyfriend or girlfriend. Because the term boyfriend or girlfriend may not have been well understood by all respondents, we also asked whether they had ever "proposed" (a term commonly used by youth to denote the initiation of a romantic relationship) to someone of the opposite sex or someone of the opposite sex had proposed to them, and the proposal had been accepted; and whether they had ever secretly spent time alone with a person of the opposite sex. Youth who reported any of these experiences were considered to have had a romantic relationship and were asked whether they had had sex with their romantic partner(s). Respondents were also asked whether they had ever had sex with a casual partner or their spouse before marriage (if the spouse had not been a romantic partner), whether they had ever had forced sex (as victim or perpetrator), whether they had ever exchanged gifts or favors for sex, and (asked of young men only) whether they had ever had sex with a sex worker or married woman. Respondents who reported having had sex with any of these nonromantic partners or under any of these circumstances were considered to have had sex with "other" partners. In answering these questions, married respondents were asked to recall their sexual experiences (with their spouse or others) prior to marriage.

Peer and parental influences were captured by three indicators. The measure of peer connectedness assessed whether youth would confide in a peer about problems with friends or male-female relationships; respondents aged 20 or older were asked to recall the situation when they were about 15-18 years old. Peers' premarital sexual experience was assessed by anonymous third-party reporting: Respondents reported the premarital sexual experiences of up to five same-sex peers. Finally, we included an indicator of parental connectedness: Youth were asked whether they would confide in their father or mother about problems with friends or male-female relationships. Again, respondents aged 20 or older were asked to recall the time when they were $15-18$ years old.

We included a community-level variable indicating the economic status of the respondent's current neighborhood. We first calculated each respondent's household economic status, using a wealth index based on ownership of certain household assets. To calculate the neighborhood economic status, we aggregated individual scores at the primary sampling unit level; to reduce the correlation between household and neighborhood economic status, we removed the respondent's score from the aggregate value (a procedure known as the jackknife method). Information on household economic status at the time of premarital sexual initiation was not collected; hence, the measure of neighborhood economic status should be treated as a proxy, especially for married young women.

Finally, because a regional pattern was observed for many measures-for example, youth in the three northern 
states tended to be more disadvantaged than those in the remaining states-we used a variable indicating three regions: northern (Bihar, Jharkhand and Rajasthan), southern (Andhra Pradesh and Tamil Nadu) and western (Maharashtra).

\section{Analysis}

We first present descriptive data on condom use and the characteristics of youth who had engaged in premarital sex. We examine gender differences in these variables using t tests or chi-square tests. Correlates of condom use are assessed separately for young women and young men using multivariate logistic regression analysis. Just 5\% of young women who had had premarital sex had used a condom at first sex, ${ }^{43}$ and only $3 \%$ had always used condoms; ${ }^{33}$ hence, we explore correlates of condom use at first sex and consistent condom use for young men only. Moreover, because information on condom use at last sex was collected only from unmarried youth, findings pertaining to this indicator are presented for the unmarried sample only (392 females and 986 males). One unmarried male respondent was excluded from the logistic regression analyses because of missing data.

To analyze the qualitative data, we developed a coding scheme and used it to code transcripts in ATLAS.ti. The coded blocks of text related to specific themes were analyzed to capture typical patterns and exceptions. Qualitative data were used both to complement survey findings and to supplement them with insights on potential correlates about which the survey did not gather sufficient data (e.g., awareness of condoms prior to engaging in premarital sex, and young peoples' risk perceptions related to infections and pregnancy).

\section{RESULTS}

\section{Background Characteristics and Condom Use}

Most of the background characteristics of our sample differed by gender (Table 1).* Females, on average, were younger than males (mean, 19 vs. 20 years) and had initiated sex at a younger age ( 16 vs. 17); in addition, they were more likely than males to report having had premarital sex only with romantic partners (67\% vs. 43\%). Young women who had had sex with nonromantic partners generally had had forced or transactional sex, while young men's nonromantic partners were typically married women, sex workers or casual partners (not shown). In general, the premarital sex that respondents reported had been unprotected: Only $7 \%$ of young women and $27 \%$ of young men had ever used condoms in premarital relationships, and only 3\% and 13\%, respectively, had always used a condom (Table 2 , page 174 ). Just $5 \%$ and $18 \%$ of young women and young men, respectively, had used a condom at first sex. Among

*Although the youth who participated in the larger study from which our data were drawn were representative of India's youth population (source: reference 33), our subsample (i.e., youth who had had sex before marriage) is a self-selected group, and their characteristics may well differ from those of the overall youth population.
TABLE 1. Selected background characteristics of married and unmarried Indian youth aged 15-24 who had had premarital sex, by gender, 2006-2008

Characteristic

Women Men $(\mathrm{N}=821) \quad(\mathrm{N}=1,587)$

Mean age (yrs.)***

$19.3 \quad 20.2$

Mean age at first sex***

15.9

17.4

Yrs. of schooling completed at first sex ${ }^{* * *}$

0

$1-7$

8-11

$\geq 12$

Worked before age $15^{* * *}$

Yes

No

Residence

Urban

Rural

$24.2 \quad 10.5$

$38.0 \quad 35.1$

$31.1 \quad 45.0$

6.7

9.5

Religion***

Hindu

Muslim

Other

45.5

54.5

34.6

65.4

19.8

80.2

19.8

80.2

Caste*

Scheduled tribe

Scheduled caste

Other backward caste

General caste

79.9

5.4

14.8

84.3

8.8

6.9

Frequent exposure to television/films ${ }^{* * *}$

No

Received family life/sex education

Yes

No

21.2

29.5

36.2

13.1

14.4

27.0

40.9

17.7

32.9

67.1

22.9

77.1

Able to confront someone who said/did something wrong***

Yes

No

Uncomfortable approaching provider/ pharmacist for contraceptives***

Yes

No

16.7

13.8

$83.3-86.2$

34.8

49.0

51.0

Type of premarital sex partners***

Romantic only

Other only

Both

Confided in peers***

Yes

No

65.2

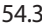

36.1

63.8

43.4

48.2

$\begin{array}{rr}15.2 & 48.2 \\ 17.5 & 8.5\end{array}$

Had peers who had had premarital sex ${ }^{* * *}$

Yes

No

Confided in parents

Yes

No

Mean neighborhood wealth score*

Region

Northern

Southern

47.

$$
52.9
$$

Western

${ }^{*} \mathrm{p} \leq .05 .{ }^{* * *} \mathrm{p} \leq .001$. Notes: All values are percentages unless otherwise noted.

$P$ values refer to gender difference in mean or percentage distribution. 
TABLE 2. Prevalence of condom use among Indian youth during premarital sex, by gender

\begin{tabular}{lcl} 
Measure & $\begin{array}{c}\text { Women } \\
(\mathrm{N}=821)\end{array}$ & $\begin{array}{l}\text { Men } \\
(\mathrm{N}=1,587)\end{array}$ \\
\hline Ever-use & 6.8 & 26.7 \\
Consistent use & 2.5 & 12.7 \\
Use at first sex & 5.0 & 18.0 \\
Use at last sex† & 13.8 & 28.4 \\
\hline tAmong unmarried women $(\mathrm{N}=392)$ and men $(\mathrm{N}=986)$. &
\end{tabular}

unmarried respondents, $14 \%$ of females and $28 \%$ of males had used a condom at last sex.

\section{Correlates of Premarital Condom Use}

In multivariate analyses, more variables were correlated with condom use among young men than among young women. Notably, no social or demographic covariates were correlated with condom use among young women, while two such variables, age at sexual initiation and schooling completed at time of premarital sexual initiation, were associated with condom use among men (Table 3). For all four condom use measures, the odds of use increased with age at sexual initiation (odds ratios, 1.1 per year for each). Compared with young men without schooling, those who had some formal education had 2.1-2.6 times the odds of having used a condom at first sex.

Sexually experienced unmarried youth who felt uncomfortable approaching a provider or a pharmacist for contraceptives generally were half as likely as those who did not feel uncomfortable to have used a condom; while among young women discomfort was associated only with condom use at last sex, among young men it was associated with all four measures of condom use (odds ratios, $0.5)$.

Qualitative data from young men confirm that their discomfort in approaching anyone for contraceptives and their lack of access to these products prevented many from practicing protected sex, especially in rural areas:

"I had seen but had never used [a condom]. These are available in the hospital, but no one gives them to children like us."-Unmarried male, rural, Rajasthan

"I was hesitant to ask anyone [for a condom] and we didn't use anything."-Married male, rural, Rajasthan

"In our village, we don't have condoms; I can't buy [them] from outside. As a precaution, I take a bath after having sex."-Married male, rural, Tamil Nadu

"Anyone who needs condoms in our village can't get them. They are available only in town. One feels shy to ask for condoms in the shop. This is the reason why many villagers don't use [them]."-Married male, rural, Andhra Pradesh

Associations between condom use and partner type were significant for both sexes, but patterns differed markedly. Compared with young women who had had premarital sex only with romantic partners, those who had had premarital sex only with nonromantic partners were significantly less likely to have used a condom at last sex
(0.2). In contrast, compared with young men who had had sex only with romantic partners, those who had engaged in sex only with nonromantic partners had 1.5-1.6 times the odds of having ever used a condom, having used a condom at last sex and having used condoms consistently. Qualitative data from young men indicate that the elevated likelihood of condom use with nonromantic partners may partly reflect differences in young men's perceptions of the risk posed by sex with some types of partners, differences in young men's preparations before engaging in sex with certain partners, their awareness of the importance of using condoms during encounters with sex workers and the availability of condoms in such instances:

"That girl was not a sex worker. I read that only sex workers suffer from these diseases."-Unmarried male, urban, Bihar

"[The sex worker] gave me [condoms] herself; she told me that there are chances of getting some disease if I don't use [them].... I didn't take any precaution with my girlfriend, as nothing happens when we do it just once or twice."-Unmarried male, rural, Bihar

"I didn't use anything with her as she had been sterilized, and moreover, she was a married woman.... I did use condoms when I had sex with sex workers; they gave me condoms... [and] even counseled me that I should practice safe sex."-Unmarried male, urban, Jharkhand

"She was a virgin.... Why be afraid of [contracting a disease]?... I had used a condom when I had sex with a sex worker; she gave me the condom. I didn't enjoy it." -Unmarried male, urban, Maharashtra

"I did not use anything with her... I would have been afraid of contracting a disease had I gone to any other girl. She is my uncle's daughter... [The sex worker] told me I can have sex with her [only if I use a condom]. I told her, 'I don't know how to put on condoms and why should I use [them]?' She just replied that I have to use." -Unmarried male, rural, Tamil Nadu

Both of the peer-level factors were correlated with condom use among young women, but only one was correlated with use among young men. Young women who reported having peers as confidantes and those who reported having peers who had had premarital sex had elevated odds of having ever used condoms (odds ratios, 3.3 and 1.9 , respectively); young men who reported having peers who had had premarital sex were not only more likely than those without such peers to have ever used condoms, but also to have used condoms at first sex and at last sex and to have used them consistently (1.6-2.9). Responses to in-depth interviews indicate that peers serve as a major source of information on contraceptive methods and condom use; among young men, they also provide advice on where to obtain condoms and how to use them, and even help procure them:

"I got to know about [condoms] from TV and [my boyfriend's] sister, because she had had sex with her boyfriend. She told me about it."-Unmarried female, urban, Bihar 


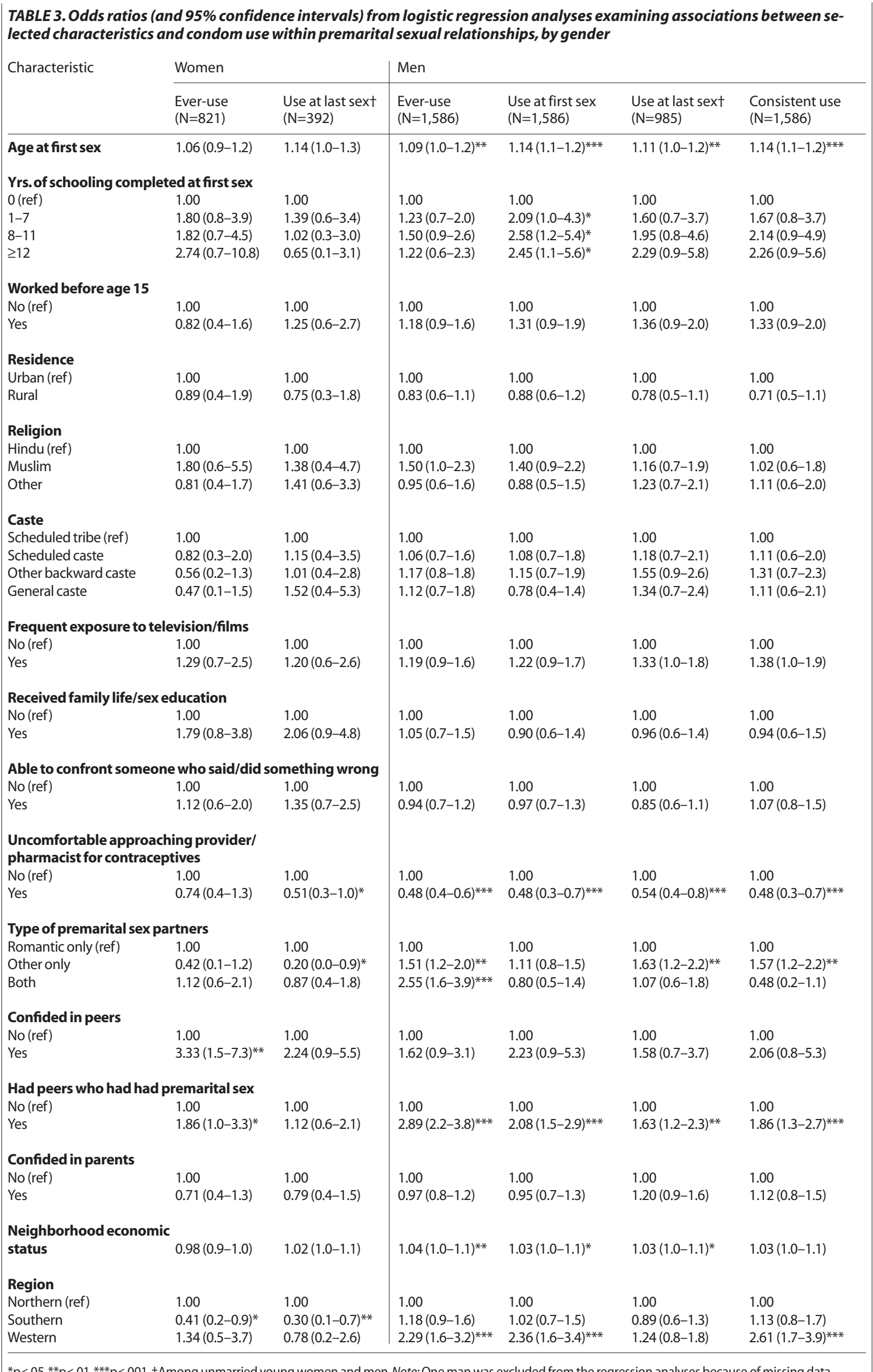

${ }^{*} \mathrm{p}<.05 .{ }^{* *} \mathrm{p}<.01 .{ }^{* * *} \mathrm{p}<.001$. †Among unmarried young women and men. Note: One man was excluded from the regression analyses because of missing data. 
"[My friends] told me how to put on the condom. They gave it to me after they purchased it from the shop." -Unmarried male, urban, Maharashtra

"My friends told me that [my girlfriend] will get pregnant if I don't take precautions and gave me [a condom]." -Married male, rural, Tamil Nadu

"Once I went to a fair with my friends. One of my friends bought [a condom] and then I asked him what it was, and he told me that it was a condom. Then, I also got it from there."-Unmarried male, rural, Bihar

Neighborhood economic status was not related to condom use among young women; however, among young men, those residing in wealthier neighborhoods were more likely than those in poorer ones to have ever used condoms, to have used a condom at first sex and to have used a condom at last sex (odds ratios, 1.03-1.04 per oneunit increase in wealth score).

Regional patterns in condom use were also apparent. Young women from southern states were less likely than their northern counterparts to have ever used a condom in a premarital relationship (odds ratio, 0.4 ) or, if currently unmarried, to have used one at last sex (0.3). Among young men, the pattern of premarital condom use was somewhat different: Compared with their peers in northern states, those in the western state of Maharashtra were more likely to have ever used a condom (2.3), used a condom at first sex (2.4) or consistently used a condom (2.6).

Responses from the in-depth interviews indicate that perceived lack of risk of becoming (or getting someone) pregnant or contracting STIs, as well as willingness to take on such risks, may underlie nonuse of condoms among many youth. For example, of the 106 young women who discussed whether they had felt at risk of becoming pregnant when they had had premarital sex, only 40 reported that they had been worried about pregnancy. Seven said that they had not felt at risk because their partner had used condoms or because they had practiced the "safe period" method of contraception. The rest had not worried about becoming pregnant: Some had been certain that they would marry their boyfriend (13 of these 19 young women were from southern states); some had held misconceptions about sex and pregnancy, such as believing that a woman cannot get pregnant if she has sex rarely or just once (14 of these 18 were from northern states); and three young women (all from southern states) had thought it would be easier to get parental approval to marry their partner if they became pregnant. For example:

"We didn't use [contraceptives] because my [partner] told me that it would be easier to get married if I got pregnant. We were hesitating to tell our parents about our affair, but they would automatically get to know if I got pregnant and would then arrange for our marriage. That was my [partner's] plan."-Unmarried female, rural, Andhra Pradesh

"I didn't use [contraceptives]; he also didn't use. Since I was going to get married to him, I was not afraid at all." -Married female, rural, Tamil Nadu
"By just doing it once, females do not get pregnant." -Married female, urban, Maharashtra

"I didn't know what pregnancy means at that time. When I had asked my parents, they told me that they had bought the baby. So, I thought that the newborns are bought from somewhere."-Unmarried female, rural, Jharkhand

Similarly, only eight of the 51 young men who discussed pregnancy risk reported that they had been worried about their partner becoming pregnant. Another nine said that they had used condoms. The rest had been unconcerned about pregnancy; reasons included lack of information about conception, the perception that their partner (particularly if she was married) knew how to prevent pregnancy herself, intentions to impregnate their partner to facilitate marrying her or overcoming parental objections, and feeling confident their partner could terminate an unwanted pregnancy. For example:

"There was no question of taking any precaution, as it would be easier to get married if she got pregnant." -Married male, rural, Tamil Nadu

"We didn't use anything, as we didn't know at that time about contraceptives or pregnancy."-Married male, rural, Jharkhand

"If she [had become] pregnant, I would have given her some pills. There are tablets to get a pregnancy aborted." -Married male, rural, Rajasthan

"She knew how to avoid a pregnancy; even if she becomes pregnant, she knows how to abort."-Married male, rural, Andhra Pradesh

In addition, most respondents who had had premarital sex had not perceived themselves to be at risk of contracting an STI. Just 18 of the 64 young women who discussed this topic during the in-depth interviews had believed that they could contract an infection, and two others reported that their partner had used condoms. Twelve women had not perceived themselves to be at risk of contracting an STI because they had trusted their partner (all but two of these women were from southern states), and 19 others (including 11 from northern states) either had not been aware of STIs or had had misconceptions about them (e.g., believing that a woman will not contract an infection if she rarely has sex). Women offered explanations such as these:

"We did not need [condoms]. As we had no disease, I was never scared of getting any disease.... He had sex with me only, I know him very well.... We never had relations with anyone else."-Married female, rural, Tamil Nadu

"I was not aware of [STIs]; I was very young at that time, just 15 years old."-Married female, rural, Jharkhand

"I never thought of [infections]. Which disease can one get by engaging in sex?"-Unmarried female, rural, Bihar

Responses were similar among young men. Only six of the 61 who discussed this topic reported that they had felt that they could contract an STI, and four others had not worried about infection because they had used condoms. The rest had not perceived any risk, primarily for the same reasons reported by young women. For example:

"I didn't use anything because she [was] my girlfriend; 
I didn't worry about anything because I knew her before and vice versa."-Unmarried male, rural, Andhra Pradesh

"I did not use [a condom]. It was not available to me; I didn't know much about it. Moreover, she was young and she didn't have anybody before."-Unmarried male, urban, Maharashtra

"I wasn't scared of anything, as I didn't have any knowledge then."-Married male, rural, Jharkhand

Qualitative findings also suggest that misconceptions and lack of awareness may compromise the ability of youth to negotiate condom use and practice protected sex. Of the 97 young women and 106 young men who reported during in-depth interviews that they had had unprotected sex, 29 and 33, respectively, said that they had been unaware of condoms when they had had sex, and many others had had misconceptions. The following comments illustrate these issues:

"I wasn't aware of [contraceptives]; he should have taken care of it, [right]?"-Married female, urban, Jharkhand

"I knew about [contraceptives], but we didn't use [them] because one doesn't get pregnant by having sex just once."-Unmarried female, rural, Andhra Pradesh

"I didn't know much about condoms. I didn't know where one gets all those things."-Unmarried male, rural, Rajasthan

"We were too young at that time, so we didn't use anything. We didn't have any [fear of AIDS], as it was not very common then. I told you that I was just 15 years old then, and now I am 24 years old. Would there have been contraceptives at that time? No one knew about AIDS 10 years back; I only came to know about AIDS four to five years back."-Unmarried male, urban, Bihar

"I used to avoid having sex when my girlfriend had her periods."-Unmarried male, urban, Bihar

"I didn't know how to use a condom; hence, I didn't use it."-Unmarried male, rural, Andhra Pradesh

Finally, the unplanned nature of premarital sex was mentioned by a few young women and by 19 young men as a reason for not using condoms:

"He came to my house unexpectedly. So we had sex unexpectedly. Hence, we didn't use anything."-Married female, rural, Andhra Pradesh

"We didn't plan that we would be making love on that day; that's why we were not able to take any precautions." -Unmarried female, urban, Jharkhand

"Would I ... [have] gone to the market to purchase a condom at that time? [The sex] just happened unplanned. Moreover, [a condom] is not required at the first time." -Married male, urban, Rajasthan

"I didn't have that much time to get those things and we were too busy to use any kind of contraceptives at that time."-Unmarried male, rural, Jharkhand

\section{DISCUSSION}

Our findings highlight that premarital sexual experiences were unprotected for most youth. Although our measures are not exactly comparable to those of previous studies, the levels of condom use in our sample were lower than those observed in earlier research. ${ }^{1,3-7}$ However, our results corroborate findings of previous studies ${ }^{1,3,6}$ in that young women were less likely than young men to report condom use within premarital relationships.

Our multivariate analyses revealed three major correlates of premarital condom use among young women and men. First, perceptions of having limited access to reproductive health services were inversely correlated with use, a finding consistent with observations in earlier studies that the lack of privacy and social stigma associated with obtaining condoms were major barriers to condom use by adults in India. ${ }^{16}$ Second, youth who reported having peers who had had premarital sex were more likely than others to have used condoms. As indicated by the qualitative evidence, peer networks may provide a venue for youth to share information about protective actions (including condom use) and about their experiences, which may motivate youth to practice protected sex. Third, although partner type mattered for both sexes, the direction of association differed. Young women were more likely to report condom use with romantic partners than with other partners, likely because those who had had sex with romantic partners had had more time to plan for protection, while those who had had sex with others may have been unable to negotiate condom use (particularly if these encounters involved forced or transactional sex). In contrast, young men who had had sex only with nonromantic partners were more likely than those who had had sex only with trusted partners to have used condoms. This finding, which has been observed in India and elsewhere, ${ }^{19,44-47}$ may be attributable to heightened concern about the risk of contracting infections from nonromantic partners and increased awareness of and access to condoms among members of high-risk groups, such as sex workers. In addition, our qualitative findings suggest that many youth may not have used condoms because they did not think they were at risk for pregnancy or STIs, or because they lacked knowledge about contraceptives.

Some factors were correlated with condom use only among young men. First, we found a positive correlation between level of schooling at the time of premarital sexual initiation and condom use at first sex, a finding observed in other studies ${ }^{22}$ and likely attributable to better-educated young men's having more information and resources to adopt protective actions than other men. Second, as observed in previous studies, ${ }^{21,22,25,27-29,48}$ later sexual initiation was positively associated with condom use. Again, it is likely that young men who initiated sex at an early age lacked information about condom use, sources of supplies and the resources to obtain condoms; in addition, they may have felt embarrassed about obtaining condoms.

We also observed regional differences. Young women from southern states were less likely than those from northern states to report condom use. Results from our indepth interviews suggest that young women from southern states were especially likely to plan on marrying their 
premarital sex partner, a finding also observed elsewhere in India. ${ }^{33}$ Consequently, young women from southern states may have been less likely than their northern counterparts to be concerned about becoming pregnant or contracting an infection. Among young men, those from the western state of Maharashtra were more likely than those residing in northern states to have used condoms within premarital relationships.

\section{Limitations and Conclusion}

The study has a number of limitations. Condom use may have been underreported, particularly by young women. Recall bias may also have influenced reports of condom use; however, study participants, especially those who provided in-depth interviews, appeared to recall their sexual experiences quite clearly, including whether they had used condoms, where they had obtained them and their reasons for nonuse.

In addition, because our study was cross-sectional, we cannot infer causation among variables or establish the temporal order of some measures; hence, the findings need to be interpreted cautiously. Likewise, the measure of neighborhood economic status does not necessarily reflect the neighborhood status at the time of the respondent's premarital sexual experiences. We also note that the way topics were covered in the in-depth interviews differed among participants, reflecting, in many instances, the respondent's willingness to discuss certain topics and the interviewer's ability to draw out pertinent experiences. As a result, narratives on some topics were richer than those on others.

Despite these limitations, the study makes several new and important contributions to understanding which youth in India are most likely to make a safe transition to sexual life before marriage, a subject about which information is scant. The findings call for repositioning the condom as a suitable method for youth. Bold and imaginatively designed communication programs aimed at youth should be implemented to dispel misconceptions and encourage condom use; at the same time, changes in the service delivery structure need to be made to enable youth to obtain condoms easily and confidentially. Findings also suggest a need to place far more emphasis than currently appears to be the case on provider training, sensitization and orientation, and on ensuring that providers are both comfortable about offering the range of services that unmarried youth need, and sensitive to the special needs, heterogeneity and vulnerability of unmarried young women and men. Efforts must ensure that providers can adapt strategies appropriately to reach unmarried youth in nonthreatening and nonjudgmental ways.

\section{REFERENCES}

1. International Institute for Population Sciences (IIPS) and Macro International, National Family Health Survey (NFHS-3), 2005-06: India, Vol. 1, Mumbai: IIPS, 2007.

2. Parasuraman S et al., A Profile of Youth in India: National Family Health Survey (NFHS-3), India, 2005-06, Mumbai: IIPS; and Calverton, MD, USA: ICF Macro, 2009.
3. Alexander M et al., Romance and sex: pre-marital partnership formation among young women and men, Pune district, India Reproductive Health Matters, 2006, 14(28):144-155.

4. Awasthi S and Pande VK, Sexual behavior patterns and knowledge of sexually transmitted diseases in adolescent boys in urban slums in Lucknow, North India, Indian Pediatrics, 1998, 35(11):1005-1009.

5. Collumbien M, Das B and Campbell OMR, Why are condoms used and how many are needed? Estimates from Orissa, India, International Family Planning Perspectives, 2001, 27(4):171-177 \& 216.

6. Kumar GA et al., Behavioral surveillance of premarital sex among never married young adults in a high HIV prevalence district in India, AIDS and Behavior, 2011, 15(1):228-235

7. Sachdev P, AIDS/HIV and university students in Delhi, India: knowledge, beliefs, attitudes and behaviors, Social Work in Health Care, 1998 26(4):37-57.

8. Santhya KG, Jejeebhoy SJ and Ghosh S, Early Marriage and Sexua and Reproductive Health Risks: Experiences of Young Women and Men in Andhra Pradesh and Madhya Pradesh, India, New Delhi: Population Council, 2008.

9. Bhattacharya $G$, Sociocultural and behavioral contexts of condom use in heterosexual married couples in India: challenges to the HIV prevention program, Health Education \& Behavior, 2004, 31(1):101117.

10. Blankenship KM et al., Power, community mobilization, and condom use practices among female sex workers in Andhra Pradesh, India, AIDS, 2008, 22(Suppl. 5):S109-S116.

11. Bloom SS and Griffiths PL, Female autonomy as a contributing factor to women's HIV-related knowledge and behaviour in three culturally contrasting states in India, Journal of Biosocial Science, 2007 39(4):557-573

12. Chakrapani V et al., Prevalence and contexts of inconsistent con dom use among heterosexual men and women living with HIV in India: implications for prevention, AIDS Patient Care and STDs, 2010, 24(1):49-58.

13. Decker MR et al., Indian men's use of commercial sex workers: prevalence, condom use, and related gender attitudes, Journal of Acquired Immune Deficiency Syndromes, 2010, 53(2):240-246.

14. Ghose T et al., Mobilizing collective identity to reduce HIV risk among sex workers in Sonagachi, India: the boundaries, consciousness, negotiation framework, Social Science \& Medicine, 2008, 67(2):311-320

15. Newman PA et al., Determinants of sexual risk behavior among men who have sex with men accessing public sex environments in Chennai, India, Journal of LGBT Health Research, 2008, 4(2-3):81-87.

16. Roth J, Krishnan SP and Bunch E, Barriers to condom use: results from a study in Mumbai (Bombay), India, AIDS Education and Prevention, 2001, 13(1):65-77.

17. Saggurti N et al., HIV risk behaviours among contracted and noncontracted male migrant workers in India: potential role of labour contractors and contractual systems in HIV prevention, AIDS, 2008 22(Suppl. 5):S127-S136.

18. Vigneshwaran E et al., Evaluation of barriers in condom use-a cross sectional survey, International Journal of Research in Pharmaceutical and Biomedical Sciences, 2011, 2(2):510-515.

19. Potdar R and Mmari K, Factors influencing sexual initiation, multiple partners and condom use among male slum youth in Pune, India, Global Public Health, 2011, 6(8):843-858.

20. Sharma V and Sharma A, Adolescent boys in Gujarat, India: their sexual behavior and their knowledge of acquired immunodeficiency syndrome and other sexually transmitted diseases, Journal of Developmental and Behavioral Pediatrics, 1997, 18(6):399-404.

21. Juarez F and LeGrand T, Factors influencing boys' age at first intercourse and condom use in the shantytowns of Recife, Brazil, Studies in Family Planning, 2005, 36(1):57-70.

22. Lugoe WL, Klepp KI and Skutle A, Sexual debut and predictors of condom use among secondary school students in Arusha, Tanzania, AIDS Care, 1996, 8(4):443-452.

23. Meekers D and Klein M, Determinants of condom use among young people in urban Cameroon, Studies in Family Planning, 2002 33(4):335-346 
24. O'Leary A et al., Predictors of safer sex on the college campus: a social cognitive theory analysis, Journal of American College Health, 1992, 40(6):254-263.

25. Prata N et al., Relationship between HIV risk perception and condom use: evidence from a population-based survey in Mozambique, International Family Planning Perspectives, 2006, 32(4):192-200.

26. Santelli JS et al., Timing of alcohol and other drug use and sexual risk behaviors among unmarried adolescents and young adults, Family Planning Perspectives, 2001, 33(5):200-205.

27. Coker AL et al., Correlates and consequences of early initiation of sexual intercourse, Journal of School Health, 1994, 64(9):372-377.

28. Ford K, Sohn W and Lepkowski J, Characteristics of adolescents' sexual partners and their association with use of condoms and other contraceptive methods, Family Planning Perspectives, 2001, 33(3):100$105 \& 132$.

29. Miller KS, Clark LF and Moore JS, Sexual initiation with older male partners and subsequent HIV risk behavior among female adolescents, Family Planning Perspectives, 1997, 29(5):212-214.

30. Jaccard J, Dittus PJ and Gordon VV, Maternal correlates of adolescent sexual and contraceptive behavior, Family Planning Perspectives, 1996, 28(4):159-165\& 185

31. Whitaker DJ et al., Teenage partners' communication about sexual risk and condom use: the importance of parent-teenager discussions, Family Planning Perspectives, 1999, 31(3):117-121.

32. Office of the Registrar General and Census Commissioner, Government of India, Socio-cultural aspects: age groups, no date, $<$ http://www.censusindia.gov.in/Census_Data_2001/Census_Data_ Online/Social_and_cultural/Age_Groups.aspx>, accessed Nov. 27, 2008.

33. IIPS and Population Council, Youth in India: Situation and Needs 2006-2007, Mumbai: IIPS, 2010.

34. Ministry of Statistics and Programme Implementation, Government of India, Gross state domestic product at current prices, 2008, <www.mospi.nic.in/6_gsdp_cur_9394ser.htm>, accessed Mar. $27,2008$.

35. Office of the Registrar General and Census Commissioner, Government of India, Provisional population totals paper 2 of 2011 (India \& States/UTs), 2011, <http://www.censusindia.gov.in/2011prov-results/paper2/census2011_paper2.html>, accessed Nov. 7, 2011.

36. National AIDS Control Organisation, Government of India, HIV Sentinel Surveillance and HIV Estimation in India 2007: A Technical Brief, 2008, <http://www.nacoonline.org/upload/Publication/ M\&E\%20Surveillance,\%20Research/HIV\%20Sentinel\%20Surveillance \%20and\%20HIV\%20Estimation\%202007_A\%20Technical\%20Brief. pdf $>$, accessed June 22, 2009

37. IIPS and Macro International, National Family Health Survey (NFHS-3), India, 2005-06: Andhra Pradesh, Mumbai: IIPS, 2008.

38. IIPS and Macro International, National Family Health Survey (NFHS-3), India, 2005-06: Bihar, Mumbai: IIPS, 2008.

39. IIPS and Macro International, National Family Health Survey (NFHS-3), India, 2005-06: Jharkhand, Mumbai: IIPS, 2008.

40. IIPS and Macro International, National Family Health Survey (NFHS-3), India, 2005-06: Rajasthan, Mumbai: IIPS, 2008.

41. IIPS and Macro International, National Family Health Survey (NFHS-3), India, 2005-06: Maharashtra, Mumbai: IIPS, 2008.

42. IIPS and Macro International, National Family Health Survey (NFHS-3), India, 2005-06: Tamil Nadu, Mumbai: IIPS, 2008

43. Santhya KG et al., Timing of first sex before marriage and its correlates: evidence from India, Culture, Health $\&$ Sexuality, 2010, 13(3):327-341.

44. Bailey A and Hutter I, Cultural heuristics in risk assessment of HIV/AIDS, Culture, Health E Sexuality, 2006, 8(5):465-477.

45. Manuel S, Obstacles to condom use among secondary school students in Maputo city, Mozambique, Culture, Health $\&$ Sexuality, 2005, 7(3):293-302
46. Marston C, Juarez F and Izazola JA, Young, unmarried men and sex: Do friends and partners shape risk behaviour? Culture, Health $\varepsilon$ Sexuality, 2004, 6(5):411-424.

47. Verma RK et al., Challenging and changing gender attitudes among young men in Mumbai, India, Reproductive Health Matters, 2006 14(28):135-143.

48. Stulhofer A et al., HIV/AIDS-related knowledge, attitudes and sexual behaviors as predictors of condom use among young adults in Croatia, International Family Planning Perspectives, 2007, 33(2):58-65.

\section{RESUMEN}

Contexto: Hay poca evidencia disponible acerca del uso del condón en las relaciones premaritales entre la gente joven en India.

Métodos: Se utilizaron datos de un estudio representativo a nivel subnacional para evaluar el uso que los jóvenes indios hacen del condón en las relaciones sexuales premaritales. Los análisis utilizaron datos de la encuesta aplicada a 2,408 jóvenes casados o solteros en edades de 15-24 años, que habian tenido relaciones sexuales premaritales; así como datos cualitativos proporcionados por 271 de esos jóvenes, quienes completaron entrevistas a profundidad. Se utilizó regresión logistica para identificar las características asociadas con las cuatro medidas de uso del condón (uso alguna vez, uso regular y constante, uso en la primera relación sexual y uso en la última relación sexual).

Resultados: Solamente el 7\% de las mujeres jóvenes y el 27\% de los hombres jóvenes que habian tenido relaciones sexuales premaritales habian usado condones alguna vez. En ambos sexos, la incomodidad al aproximarse a un proveedor o farmacéutico para obtener condones estuvo inversamente correlacionado con la mayoría de las medidas de uso del condón (razón de momios, 0.5), mientras que, en general, el tener pares con experiencia sexual premarital estuvo correlacionado positivamente (1.6-2.9). Las mujeres que habian tenido relaciones premaritales solamente con parejas no románticas, tuvieron menor probabilidad que aquellas con sólo parejas románticas de haber usado condón en la última relación sexual (0.2), mientras que los hombres tuvieron en general mayor probabilidad de usar condones con parejas no románticas que con parejas románticas (1.5-1.6). Entre los hombres, el nivel educativo, la edad en la iniciación sexual y la condición económica del vecindario estuvieron asociados positivamente con el uso del condón.

Conclusión: Son necesarios programas que fomenten el uso del condón por parte de los jóvenes de India. Se debe modificar la estructura de la prestación de servicios para permitir que los jóvenes obtengan condones de manera fácil y privada.

\section{RÉSUMÉ}

Contexte: L'Inde dispose de peu de données concernant l'usage du préservatif dans les relations prénuptiales des jeunes.

Méthodes: Les données d'une étude sous-nationale des jeunes Indiens et Indiennes ont servi à évaluer l'usage du préservatif dans les relations prénuptiales. Les analyses reposent sur les données d'enquête de 2.408 jeunes mariés ou non âgés de 15 à 24 ans qui ont eu des rapports sexuels avant le mariage et sur 
les données qualitatives obtenues de 271 de ces jeunes ayant participé à un entretien en profondeur. Les caractéristiques associées à quatre mesures d'usage du préservatif (usage à un moment quelconque, usage régulier, usage lors des premiers rapports sexuels et usage lors des derniers rapports) sont identifiées par régression logistique.

Résultats: Seuls $7 \%$ des jeunes fermmes et $27 \%$ des jeunes hommes qui avaient eu des rapports sexuels avant le mariage avaient jamais utilisé le préservatif. Dans les deux sexes, la gêne à l'idée de se procurer le préservatif auprès d'un prestataire ou d'un pharmacien est en corrélation inverse avec la plupart des mesures d'usage (OR, 0,5), tandis que le fait d'avoir des pairs ayant eu des rapports prénuptiaux présente généralement une corrélation positive (1,6-2,9). Les jeunes femmes qui n'ont eu de rapports prénuptiaux que dans le cadre de relations non amoureuses sont moins susceptibles d'avoir utilisé le préservatif lors de leurs derniers rapports $(0,2)$, par rapport à celles engagées dans des relations strictement amoureuses. Côté masculin, la situation inverse est observée (1,5-1,6). Parmi les jeunes hommes, le niveau d'éducation, l'âge au moment des premiers rapports sexuels et le niveau économique du quartier sont associés positivement à l'usage du préservatif.

Conclusion: Il existe un besoin de programmes qui encouragent l'usage du préservatif. Les structures de prestation doivent être modifiées pour permettre aux jeunes de se procurer facilement le préservatif, de manière discrète et confidentielle.

\section{Acknowledgments}

The authors gratefully acknowledge the support of the John D. and Catherine T. MacArthur Foundation and the David and Lucile Packard Foundation. We thank Komal Saxena, M.A. Jose and Shilpi Rampal for their support and assistance in preparing the manuscript.

Author contact:kgsanthya@popcouncil.org 